\title{
Present Management Status and Standardization Advice of Rural Collective Economic Organization
}

\author{
Xiaolei Ma ${ }^{1, a}$, Zhenyu Yun ${ }^{1, b^{*}}$, Yutong Wang ${ }^{1, c}$, Liangbing $\mathrm{Hu}^{1, \mathrm{~d}}$ and Kun $\mathrm{Luo}^{2, \mathrm{a}}$ \\ ${ }^{1}$ China National Institute of Standardization, Haidian District, Beijing, China \\ 2Jiangsu Institute of Quality and Standardization, Nanjing, Jiangsu, China \\ amaxl@cnis.gov.cn, byunzy@cnis.gov.cn \\ ${ }^{*}$ Corresponding author
}

Keywords: Rural collective economic organization, Present management status, Standardization

\begin{abstract}
The development of rural collective economic organization, is not only related to the vital interests of the broad masses of peasants, but also related to the development direction of basic rural economic system, the perfection of rural social governance system, and even the overall strategy of national development. After combing the evolution course of rural collective economic organization form, this paper analyzes the present management status of the new-style rural collective economic organization and problems existing during the development process under the background of reform of the rural collective property rights system. Meanwhile, this paper also proposes the standardization policy advice of strengthening the management of rural collective economic organization from the perspective of organization establishment, identification and adjustment of membership rights, assets management, financial management and others, as per the existing problems.
\end{abstract}

\section{Introduction}

The rural collective economic organization is an important part of China's rural collective economic system, which plays an important role in the development of China's rural economy. With the development of China's productivity and the promotion of reform, a series of evolution occurs to the organization form and management requirements of rural collective economic organization. At the different evolution stage, the management of rural collective economic organization faces variable problems, some of which will be solved and perfected during the reform promotion process, but some of which will still exist. At present, under the background of reform of the rural collective property rights system, the management of new-style rural collective economic organization still faces many problems and challenges.

As the effective tools of establishing the best order, the standardization has played the increasingly prominent role in facilitating the economic and trade exchanges, supporting the industrial development, promoting the scientific and technical progress, and normalizing the social governance. The application fields of standards have already been extended from the preliminary industry to the agriculture, service industry, social governance and other fields. It clearly demonstrates that the standards have already been gradually penetrated to all aspects of human life. In contrast to the wide application of standards to other fields, the application of standards in the rural economic development at present is still under the exploratory stage (namely, out of nothing). Whether partial problems encountered in the management of new-style rural collective economic organization will be solved via the standardization methods, has already become the new direction that is worthy of exploration and practice.

\section{Evolution course of rural collective economic organization form}

The practice of China's rural collective ownership was profoundly affected by the former Soviet Union's theory of collective ownership. The establishment of collective ownership was realized through the socialist transformation of individual ownership and in the manner of agricultural 
cooperation $^{[1]}$. As of now, the development of China's rural collective economic organization has mainly gone through 4 stages, namely, rural collective economic organization during the agricultural cooperation movement period, the village-level collective economic organization under the People's Commune "Three-Level Ownership, Production-Team Based" system, the village-level collective economic organization under the Collective and Household Two-Level Management System, and the new-style rural collective economic organization under the background of reform of rural collective property rights system.

As specified in the Model Regulations for Advanced Agricultural Producer's Cooperatives implemented in 1956, the advanced agricultural producer's cooperatives were the socialist collective economic organization of peasants organized under the leadership and assistance of Communist Party of China and People's Government, and on the voluntary and mutually beneficial basis. Its main functions are as follows: "as per the Principles of Socialism, it is required to convert the commune member's private and primary means of production into the cooperative society's collective ownership, organize the collective labor, and implement the "from each according to his ability, to each according to his needs" system. The distribution of wages shall follow the principle of distribution according to work and equal pay for equal work."

As stipulated in the Draft Amendment to Regulations on the Work in the Rural People's Communes passed in 1962, "The rural people's communes are jointly established based on the advanced agricultural producer's cooperatives, so as to adapt to the needs of production development. Within a very long period of history, the rural people's communes are the principles for the socialist collective economic organizations to implement the system "from each according to his ability, to each according to his needs; and he that works more, gets more, and that will not to work, shall not eat."

Since 1978, China's villages has started to implement the household contract responsibility system, and realized the conversion of rural land from the collective operation and management to decentralized operation and management. Thereafter, the household contract responsibility system has become one basic operation system in rural China at present. In 1984, the people's communes system was completely disintegrated. In Beijing, Guangzhou, Zhejiang and other regions where the collective economy was relatively developed, the village-level economic cooperatives, commune stock cooperatives, collective enterprises, and many rural collective economic organizations were formed.

In 2016, the Central Committee of the Communist Party of China and State Council issued the Opinion regarding the Steady Promotion of the Reform of the Rural Collective Property Rights System [ZF [2016] No. 37], which implemented the top-level design and overall deployment upon the reform of rural collective property rights system. As specified in the Opinion, the collective economic organization is the subject of collective assets management, while it will legally exercise the ownership of collective assets on behalf of the collective, and the villages (groups) with the collective assets are required to establish and perfect the rural collective economic organizations ${ }^{[2]}$. Meanwhile, the General Provisions of the Civil Law of the People's Republic of China enacted in 2017 , solved the legal person qualification problem of rural collective economic organization ${ }^{[3]}$.

\section{Present management status and problems of rural collective economic organization}

Under the grand background of reform of rural collective property rights system, the changes have gradually occurred to the organization form and operation \& management mode of China's rural collective economic organization. During the change process, China's rural collective organization has demonstrated some prominent common problems ${ }^{[4]}$.

\subsection{Ambiguous functions of collective economic organization and village self-government organization}

In the sense of connotation and denotation, the village committee and other self-government organizations, and village-level collective economic organization will have the variable degrees of difference. However, under the existing organization operation system, the functional boundary 
between them is very indistinct. Theoretically, the village-level collective economic organization and village-level "Two Committees" belong to the organizations of the variable natures, powers \& functions. Many existing laws reflect the regulations of overlapping functions between the villagelevel "Two Committees" and village-level collective economic organization. For instance, it is stipulated in the Article 74 of General Provisions of the Civil Law of the People's Republic of China, "Collectively owned land shall be owned collectively by the village peasants in accordance with the law and shall be worked and managed by village agricultural production cooperatives and other collective agricultural economic organizations or villagers' committees". In addition, it is further stipulated in the Article 8 of Organic Law of the Villagers' Committees of the People's Republic of China, "The villagers' committee shall, in accordance with the law, administer affairs concerning the land and other property owned collectively by the villagers". However, it is also stipulated, "A villagers' committee shall respect the decision-making power of the collective economic organizations in conducting their economic activities independently according to law". The relevant laws and regulations empowered the village-level collective economic organizations (villagers' committee and villagers' electoral committee) and village-level collective economic organization to have the rights to possess and manage the rural lands and other collective assets. The same legitimacy is granted to both of them. However, who shall have the rights to handle the rural collective assets is still not clearly stipulated by the law.

From the perspective of the reform of the existing property rights system, most collective economic organizations and village-level "Two Committees" have the overlapping functions, but neither of them performs their own functions. The village-level collective economic organization undertakes the public management functions and cost expenditure of villagers' committee or community, all of which have brought great burdens to the development of rural collective economic organizations, and even locally caused the conflicts between the members of the collective economic organization and villagers' committee or villagers.

\subsection{The non-uniform definition manner for members of collective economic organizations}

The rural collective assets are a sort of special properties, while the problem of collective assets will be always linked with the identity of collective membership. China's existing collective land system and collective asset possession are realized on the premise that the subject of property rights has the long-term stability. Due to the constant turnover and change of the family members, the contradiction occurs to the collective asset ownership and collective membership. The confusion between the village-level collective economic organization and village self-government organization brings a certain difficulty to the qualification identification of collective membership of variable natures. With regard to how to define the membership of collective economic organization, there is still no definite legal regulation. The access path of the membership qualification and definition manner of democracy are infinitely varied, while the definition of collective organization's membership qualification demonstrates the diversified and complex features in terms of rural resident status, household, land and etc. Meanwhile, the change of organization membership causes the difficulty in the adjustment of collective assets.

\subsection{Inadequate evidences and constraints for the management of rural collective assets}

Generally, the rural collective assets fall into three categories, namely, operating assets, nonoperating assets and resources assets. For the scope of stock reduction quantification of collective assets, at present, the competent authority has still not prepared the unified standards, and the great difference still exists in the manner of assets quantification. From the actual operation perspective, the three categories of assets may be either quantified by classification, or synchronously quantified, or orderly quantified. From the perspective of system change of collective land ownership, after the implementation of household contract responsibility system, there is no unified definite legal regulation regarding the specific level at which the subject of collective land ownership falls (the land ownership of variable regions has the differences of villagers' electoral committee, village collective economic organization and village and town collective economic organization). With the 
change of the ownership and purpose of this sort of lands, the new difficulties occur to the stock reduction quantification of collective assets.

The income distribution of collective organization members is closely related to the land acquisition, house demolition, old village reconstruction, land transfer and etc. Therefore, the interest distribution problem of the collective economic organization members is intricate. The lateral transfer of collective assets, the control of collective assets by a minority, "small officials, big corruption" and other phenomena locally occur. Therefore, it is hard to protect the peasant's collective income distribution rights.

\subsection{Pending regulation of financial management of collective economic organization}

With the rapid growth of rural economy, the government at all levels has attached increasingly great significance to the pattern strengthening and regulation of rural financial management. When carrying out the financial management works, partial rural collective economic organization may properly handle the most fundamental financial budget and settlement works, utilize the funds in a relatively efficient manner, and basically follow the requirements of financial management system to conduct the operation. However, due to the effects of absence of supervision, weak financial management awareness, low quality level of financial staffs, imperfect rural financial management system, confusion of villagers' committee funds and collective economic organization funds, and other factors, the confused funds management, loss of assets, poor regulation and other phenomena still exists in the financial management of rural collective economic organization to variable degrees.

\section{Advice of standardization policy}

With regard to the main problems existing in the management of rural collective economic organization, it is found that some problems may be solved or optimized with the standardized methods, after the analysis is made with the standardized methods.

\subsection{Standardization of organization establishment}

The establishment standardization of rural collective economic organization is the effective method to solve the ambiguous functions of collective economic organization and village self-government organization. At present, in terms of establishment of rural collective economic organization, Jiangsu, Guangxi and other regions have already made the active explorations, and enacted the corresponding administrative measures. However, it is found that differences exist among variable provinces with regard to the establishment procedure, contents and etc., via the comparison and analysis. In addition, the requirements are not detailed enough. After the rural collective economic organization was confirmed as the special legal person as per the provisions of General Provisions of the Civil Law of the People's Republic of China enacted in 2017, the Ministry of Agriculture and Rural Affairs, People's Bank Of China, and State Administration for Market Regulation issued the Notice on Carrying Out the Registration and Code Assignment Works of Rural Collective Economic Organization in 2018. The commencement of registration and code assignment works of rural collective economic organization laid a solid foundation for the standardization of organization establishment. For the establishment of rural collective economic organization, it is firstly recommended to give the unified establishment principle, such as collective ownership, adaption to the local conditions, village-oriented and other principles. Under the premise that the establishment principles are conformed to, it is required to establish the scientific and reasonable procedure, by applying the standardized methods to comb the common procedures for the local establishment of rural collective economic organization, and combining the registration and code assignment working requirements of China's rural collective economic organization. Meanwhile, it is recommended to standardize the establishment of rural collective economic organization in terms of the composition of organizational structure, scope of responsibility, rules of procedure, Articles of Association, and etc., explore the establishment of organizational structure consisting of the general meeting of member or member representative, governing body and supervisory board, define the 
responsibility scope and rules of procedures of each organization, and standardize the contents of Articles of Association.

\subsection{Standardization of membership identification and adjustment}

The membership of rural collective economic organization is the main basis of income distribution. It was proposed in the Opinions on Further Promotion of Reform of the Household Registration System issued by the State Council in 2014, "It is required to promote the reform of rural collective economic organization's property rights system and explore the identification measures of membership qualification of collective economic organization". With the comprehensive launch of the property rights system reform, the beneficial exploration and attempt has been made to the membership identification and adjustment works at the pilot sites of reform. However, as of now, the national unified regulation regarding the membership identification and adjustment has still been absent at the legal level. Whether the relevant specifications may be made at first in the manner of standardization, is worthy of exploration and attempt. The standardization working proposals of membership identification and adjustment are implemented based on the conformity of the relevant existing laws, regulations and policies. Meanwhile, it is also required to consider the diversity and complexity of the local realities nationwide. According to the principles of respect for history, consideration of the actual conditions, standardized procedures, equality of men and women, recognition of the masses and openness and transparency, it is required to make the overall consideration of the household registration, relations of production and life, land contracting relationship, contribution to the collective assets accumulation and other factors, classify and define the identification conditions of membership. In addition, it is required to standardize the identification procedure based on the strict performance of democratic procedure. At the same time, it is recommended to define the conditions for the membership acquisition and loss resulted from the birth and death of members, establishment, change and termination of the organization, population migration, member identity and relationship change, and other causes.

\subsection{Standardization of assets management}

The member of rural collective economic organization has the occupation, income, offer for sale, withdrawal, guarantee and inheritance rights upon the collective asset stock. However, the loss of rural collective assets is very severe, while the root cause is that the relevant system is not perfect enough. During the management process, the scientific and reasonable collective asset management system has not been developed, which seriously affects the development of rural economy. Therefore, it is necessary to prepare and issue the unified standards at the state level, so as to standardize the assets management works of the rural collective economic organization. In order to strengthen the rural collective economic organization's assets management, it is recommended to firstly define the scope of assets management, establish and perfect the rural collective assets management requirements regarding the resources assets, operating assets and non-operating assets, and other variable assets type, including the authentic right of assets, operation \& use, setting of shares, income distribution, and etc. In addition, it is required to carry out the assets management of rural collective economic organization as per the requirements of standards, and conduct the assets supervision as per the requirements of standards, so as to solve the problem that the assets management of rural collective economic organization lacks of the constraints, and ensure the safety, and value reservation $\&$ increment of the collective assets.

\subsection{Standardization of financial management}

The financial management of rural collective economic organization is the ultimate goal of "Three Assets" management of the rural collective. With the continuous concern of the government regarding the agricultural economic development in recent years, the significant meanings of financial management works upon the agricultural economic development has become more valuable. Although China and all the regions have enacted a series of management and regulation systems, some actual problems still exist at the concrete implementation level. Therefore, it is recommended to detail and implement the scientific rural collective economic organization's 
financial management working system via the standardized methods, define the management requirements of rural collective economic organization's account, accounting archives, accounting agency, financial publicity and other contents, make the unified regulations of the village collective financial working procedure, and form the standards that the rural financial management works may refer to and execute. Meanwhile, it is required to establish and perfect the system of democratic supervision and auditing supervision and implement the standards application, through strengthening the financial management training and professional guidance of rural collective economic organization, so as to solve the problems existing in the financial management of rural collective economic organization.

\section{Summary}

In recent years, under the two-wheel driving of rural revitalization strategy and new-type urbanization strategy, China's rural economy has achieved the unprecedented development. Although partial regions in China has prepared the local policies and regulations regarding the management of rural collective economic organization, in response to the call of China's rural collective property rights system, the unified constraints are still absent. Thus, it leads to a series of problems of the management, such as the unclear definition of membership of village-level collective economic organization, ambiguous scope of collective assets, poor supervision and management, and etc. With regard to the above problems, the standardization acts as the technical method by which the best order may be achieved within a certain scope, and it is an important factor of steady promotion of standardized management of rural collective economic organization, upgrade the management quality of rural collective economic organization, and safeguard the healthy development of rural collective organization.

\section{Acknowledgment}

This research was sponsored by the scientific research project of Standardization Administration of the People's Republic of China "Preliminary Study on the Key Standards Cultivated by the Rural Collective Economic Organization".

\section{References}

[1] Dan Wang, Legal positioning of legal person of rural collective economic organization [J], The People's Judicature•Application, vol. 28, 2017.

[2] Central Committee of the Communist Party of China and State Council, Opinion regarding the steady promotion of the reform of rural collective property rights system [Z], 2016.

[3] Shuang $\mathrm{Wu}$, Construction of exit legal mechanism of rural household land contract right [N], Rural Economy, vol. 9, 2017.

[4] Zhiquan Fang, Thinking of issues on rural collective economic organization system of property rights reform in China [N], Science Development, vol. 9, 2014. 